\title{
XV-2c and KM.19 haplotype analysis in Chilean patients with cystic fibrosis and unknown CFTR gene mutations
}

\author{
GABRIELA M REPETTO $^{1}$, ALONSO R PUGA ${ }^{1}$ and IRIS DELGADO ${ }^{2}$
}

${ }^{1}$ Programa de Genética Humana and ${ }^{2}$ Instituto de Epidemiología y Políticas Públicas, Facultad de Medicina,
Clínica Alemana-Universidad del Desarrollo, Santiago, Chile

\begin{abstract}
Cystic fibrosis (CF) is caused by mutations in the CFTR gene. More than 1600 mutations have been described, with frequencies that differ worldwide according to the ethnic origin of patients. A small group of mutations are recurrent on several populations. It has been shown that they each tend occur on specific chromosome 7 haplotypes, supporting the notion of a single origin for them. Less than $50 \%$ of mutations in Chilean patients have been identified to date. To indirectly assess the possible presence of a predominant founder mutation in the remaining unknown alleles, we evaluated 2 polymorphic markers, XV-2c and KM.19, tightly linked to the CFTR locus. The study was done in Chilean CF patients with unknown or deltaF508 $(\Delta \mathrm{F} 508) \mathrm{CFTR}$ mutations and their haplotypes were compared to affected family-based controls. $\Delta \mathrm{F} 508$ showed marked linkage disequilibrium with XV-2c/KM.19 haplotype B, with $90 \%$ of alleles on that haplotype. There was no difference in haplotype distribution between unknown mutations and normal controls. These results support a European origin for $\Delta \mathrm{F} 508$ alleles in Chilean patients, and make unlikely the presence of a predominant founder mutation in the so-far unknown alleles.
\end{abstract}

Key terms: CFTR gene, cystic fibrosis, $\Delta$ F508, haplotype analysis.

\section{INTRODUCTION}

Cystic fibrosis (CF) is one of the most common life-threatening autosomal recessive diseases. It is a complex multisystem disorder, caused by mutations of the gene encoding for the cystic fibrosis transmembrane conductance regulator (CFTR), located on chromosome region 7q31. More than 1600 disease-causing mutations have been described worldwide, but only a small number, approximately 30 of them, have individual frequencies higher than $0.1 \%$ in $\mathrm{CF}$ patients and the rest have been observed in a few families each (CFGAC, 1994).

The CFTR gene was identified by positional cloning (Beaudet et al., 1989; Rommens et al., 1989). The gene was found to be tightly linked to the D7S23 locus. Polymorphisms in this locus were initially detected by restriction fragment length polymorphisms (RFLP) using probes XV$2 \mathrm{c}$ and KM.19, located 175 and $125 \mathrm{~kb}$ upstream of the 5' end of the gene. Prior to the discovery of the gene, it was shown that close to $90 \%$ of European CF patients shared a common XV-2c/KM.19 (XK) haplotype. This haplotype, designated "B", was only found in $16 \%$ of normal individuals (Beaudet et al., 1989; Kerem et al., 1989). Subsequent research confirmed that this observation reflected the presence of strong linkage disequilibrium, that is, non-random association of alleles at two or more loci on a chromosome, between the most common European mutation, deltaF508 ( $\Delta$ F508), and haplotype B. This finding supported the theory of a single origin of this mutation (Dork et al., 1992; Kerem et al., 1989; Highsmith et al., 1990; Morral, Bertranpetit et al., 1994). Several

Corresponding author: Gabriela M. Repetto, MD, Programa de Genética Humana, Facultad de Medicina, Clínica AlemanaUniversidad del Desarrollo, Av. Las Condes 12438, 771-0162 Lo Barnechea, Santiago, Chile, Phone: 5622999202 , Fax: 562299 9306, E-mail: grepetto@udd.cl 
other common mutations are predominantly present on one haplotype. For example, G542X, a mutation of high prevalence in Mediterranean countries and having the third highest frequency in Chilean patients, is also associated with XK haplotype B (Loirat et al., 1997). Mutations N1303K, G551D, W1282X, 394delTT and 3120+1 $\mathrm{G}>\mathrm{A}$ also appear to have a single origin each (Cashman et al., 1995; Osborne et al., 1992; Dork et al., 2000; Kerem et al., 1995; Shoshani et al., 1992; Dork et al., 1998). In contrast, other mutations have been found on several haplotypes, suggesting multiple origins for them (Morral, Llevadot et al., 1994).

The incidence of the disease and the distribution of the mutations differ among populations according to their ethnic origin. A group of 32 common mutations accounts for $83 \%$ of mutant alleles in Caucasian population in the USA, percentage largely attributable to the large proportion of $\Delta$ F508 alleles (Heim et al., 2001). In Chilean CF patients, the same panel of 32 mutations has a detection rate of only $50 \%$ (Puga et al 2007, manuscript under review). The remainder of local mutations has not been identified, mainly because the ones evaluated so far correspond to mutations that are common in European and North American populations (Rios et al., 1994; Repetto et al., 2001; Molina et al., 2002; Puga et al., 2007). This hinders diagnostic confirmation, particularly in atypical cases, and carrier identification.

The mutations not yet identified in our population could correspond to several of low individual frequency or alternatively, there could be a single or more common founder mutation originated on a specific haplotype. To assess these possibilities, we evaluated XV-2c/KM.19 haplotype distribution in Chilean $\mathrm{CF}$ patients with unknown CFTR mutations and compared them to $\Delta$ F508 and normal CFTR alleles.

\section{METHODS}

Peripheral blood samples were collected from patients registered in the National Cystic Fibrosis Program of Ministerio de
Salud de Chile who fulfilled diagnostic criteria for CF (Rosenstein et al., 1998), consisting in typical involvement of at least one organ system and sweat chloride concentration equal or greater than $60 \mathrm{mEq} /$ L. We only included patients that had had molecular testing in our previous study of 32 common mutations (Puga et al., 2007, manuscript under review) and evaluated 3 groups of CF patients: disease alleles not identified, $\Delta$ F508/unknown mutation heterozygotes, and $\Delta \mathrm{F} 508 / \Delta \mathrm{F} 508$ homozygotes.

To construct the XK haplotypes, blood samples from both parents were also obtained and analyzed. The protocol was approved by Comité de Ética para la Investigación, Facultad de Medicina, Clínica Alemana-Universidad del Desarrollo. Written informed consent was obtained from all participating individuals and/or their parents.

Genomic DNA was extracted from samples using Easy-DNA kit (Invitrogen, Carlsbad, CA, USA). The polymorphisms were evaluated by restriction enzyme analysis of PCR products, which allows to discriminate between two alleles at each marker based on the presence or absence of a restriction site. To analyze marker $\mathrm{XV}-2 \mathrm{c}$, genomic DNA was amplified using primers XV-2C (f): 5'-GTT GAA GTG AAT TGA ATG-3' and XV-2C(r): 5'-GTT AAA CTA TGT CAA AG-3'. The products were digested with restriction enzyme Taq I (Rosenbloom et al., 1989). For KM.19, the primers used were KM-19(f): 5'-GCT GCA TCA TAT AAG TTG CC-3' and KM-19(r): 5'-AAG GCT ACA CTG TTA ATT TT-3'. The polymorphism was analyzed with restriction enzyme Pst I(Anwar et al., 1990). PCR and restriction products were separated by electrophoresis on $2.5 \%$ agarose gels. The order of the markers on chromosome 7 and their observed recombination fractions is centromere/ $\mathrm{XV}$ 2c (0.001) KM.19 (0.006) CFTR/telomere (Lathrop et al., 1988; Beaudet et al., 1989). Haplotypes for each individual were constructed by segregation analysis of the results of the members of each family. XK haplotypes were labeled as described by Beaudet et al (1989) (see table I). 
TABLE I

Designation of XV-2c/KM.19 haplotypes (Beaudet et al.; 1989)

\begin{tabular}{ccc}
\hline Haplotype & XV-2c allele* & KM.19 allele* \\
\hline A & 1 & 1 \\
B & 1 & 2 \\
C & 2 & 1 \\
D & 2 & 2 \\
\hline
\end{tabular}

* 1 denotes absence of Taq I or Pst I restriction site, 2 indicates presence of restriction site.

Data were compiled and analyzed using SPSS version 12 (SPSS Inc., Chicago,IL). To avoid population stratification bias, we used the affected family-based controls (AFBAC) method of analysis (Thomson, 1995), in which haplotypes not transmitted by a healthy carrier parent to an affected child constitute the control or normal population. The haplotype distributions of the mutation-unknown, $\Delta \mathrm{F} 508$ and normal chromosomes were compared by $\chi^{2}$. Twotailed p-values $<0.05$ were considered to be statistically significant.

\section{RESULTS}

Samples from 52 unrelated patients with $\mathrm{CF}$ were analyzed, distributed according to genotypes as follows: 16 had both mutations unknown, 7 were $\Delta$ F508/ unknown mutation compound heterozygotes and 29 were $\Delta$ F508 homozygotes. Regarding family structure, 21 trios were complete, that is, both non-consanguineous parents were analyzed. Five families had no paternal sample available. Parental samples were unavailable for twenty-six $\Delta$ F508 homozygotes. Three of the complete trios and one child/mother duo were uninformative, i.e., the parental and/or child's haplotypes could not be clearly established and were not included in the analysis. This resulted in 37 alleles with unknown CFTR mutations, 63 bearing $\Delta$ F508 and 40 control haplotypes available for analysis.
Results for XV-2c and KM.19 RFLP analysis from a representative family and an isolated $\Delta \mathrm{F} 508$ homozygous individual are shown in Figure 1. The father on family \#005 (Fig. 1A) was homozygous for absence of the restriction site at markers XV-2c and KM.19, therefore labeled "1" for both alleles at both markers, this corresponds to haplotype A. The mother was homozygous for the presence of the Taq I restriction site in marker XV-2c (therefore " 2 ") and homozygous for the absence of the Pst I site at KM.19 ("1"). This combination corresponds to haplotype C. Their affected child inherited an A haplotype from his father and a $\mathrm{C}$ haplotype from the mother, as expected. The parental non-transmitted $\mathrm{A}$ and $\mathrm{C}$ haplotypes were counted as controls. The RFLP results of a $\Delta$ F508 homozygote are shown in Figure 2B. The individual was homozygous for absence of Taq1 restriction site at XV-2c ("1") and presence of the site at KM.19 ("2") and therefore was homozygous for haplotype B.

The distribution of XK haplotypes among the unknown mutations and normal chromosomes showed no significant differences, as shown in Table II. Most alleles in both groups were on haplotypes A and $\mathrm{C}$, followed in frequency by $\mathrm{B}$. Only $5 \%$ of normal alleles or those bearing unknown mutations were on haplotype D. In contrast, there was marked predominance of haplotype B in $\Delta \mathrm{F} 508$ chromosomes, with only one allele in each of $A$ and $C$ haplotypes and 4 alleles on haplotype D. A statistically significant difference was observed between the distribution of these haplotypes and that of normal chromosomes $\left(\chi^{2}=66.615 ; \mathrm{p}<0.000001, \mathrm{df} 3\right)$.

\section{DISCUSSION}

This study evaluated XK haplotypes in Chilean patients with $\mathrm{CF}$ but unknown mutations, and compared the results with normal, family-based control haplotypes, as well as $\Delta$ F508-bearing chromosomes.

No difference was observed in haplotype distribution between normal and unknownmutant chromosomes. This implies that we 
found no evidence of association of mutant $\mathrm{CF}$ chromosomes with a specific haplotype in this group of patients with the disease and unidentified causative mutations. This lack of association contrasts with what has been observed for several of the common mutations (Cuppens et al., 1994). The opposite was seen in Chilean $\Delta \mathrm{F} 508$ chromosomes in our study, with over $90 \%$ of them present on XK haplotype B. This finding evidences marked linkage disequilibrium between them, as it has been shown in other populations (Kerem et al., 1989; Highsmith et al., 1990; Dork et al., 1992; Morral, Bertranpetit et al., 1994). A European origin for the $\Delta \mathrm{F} 508$ mutation observed in Chilean patients is therefore suggested.
A

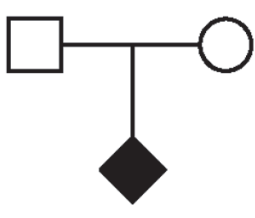

$X Y-2 c:$
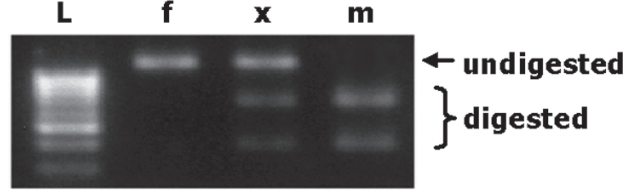

KM.19:

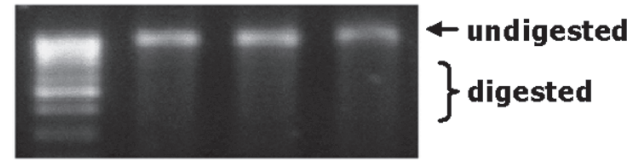

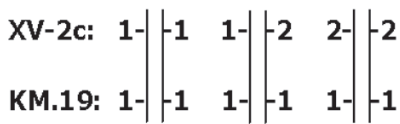

B

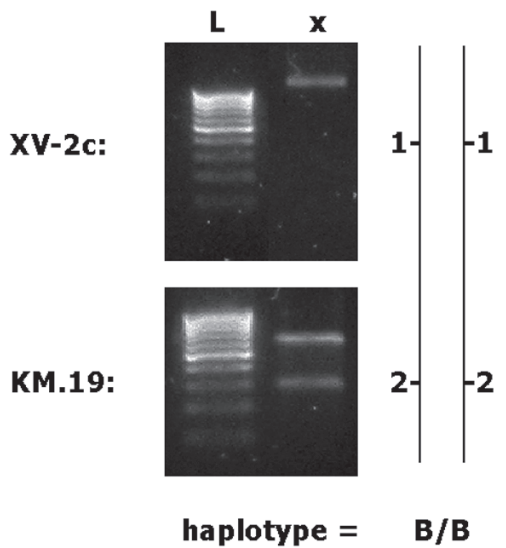

haplotype $=$

A/A A/C C/C

Figure 1: Restriction enzyme analysis in a family (A) and an isolated case (B). Electrophoresis of restriction products run in 2,5\% agarose and stained with SYBR Green. L, molecular weight ladder. Chromosome 7 regions studied for each individual are represented as vertical lines. The number in each allele represents absence (1) or presence (2) of the restriction site for Taq I or Pst I in markers XV-2c (top panel) or KM.19 (bottom panel), respectively. XK haplotypes were labeled as described on Table 1. Panel A: Family \#005, child with unknown CFTR mutations ("f": father, "x": affected and "m": mother), with their constructed haplotypes at the bottom. Panel B: Patient \#299, a $\Delta$ F508 homozygote, with the constructed haplotypes shown on the right.

TABLE II

Haplotype distribution among unknown, $\Delta \mathrm{F} 508$ and normal CF alleles, shown as number of alleles with percentages in parentheses

\begin{tabular}{|c|c|c|c|c|c|c|}
\hline & \multicolumn{5}{|c|}{ Haplotype } \\
\hline & & A & B & $\mathrm{C}$ & $\mathrm{D}$ & Total \\
\hline \multirow{3}{*}{ Mutation } & Unknown * & $12(32.4)$ & $8(21.6)$ & $15(40.5)$ & $2(5.4)$ & $37(100)$ \\
\hline & DF508 ** & $1(1.6)$ & $57(90.5)$ & $1(1.6)$ & $4(6.3)$ & $63(100)$ \\
\hline & Normal & $18(45.0)$ & $6(15.0)$ & $14(35.0)$ & $2(5.0)$ & $40(100)$ \\
\hline
\end{tabular}

$* \chi^{2}=1.405 ; \mathrm{p}=0.704$, df 3 vs. normal.

$* * \chi^{2}=66.615 ; \mathrm{p}<0.000001$, df 3 vs. normal. 
Haplotype heterogeneity for unknown mutations has been observed in other mixed Latin American populations. In Mexican patients, Orozco et al. (2001) showed that $97 \%$ of $\Delta \mathrm{F} 508$ chromosomes are on haplotype $\mathrm{B}$, but no difference in haplotype distribution between unknown mutations and normal chromosomes was found. In Brazilian patients, Raskin et al. (1997) showed that $88 \%$ of $\Delta$ F508 and only $41 \%$ non- $\Delta$ F508 were on $\mathrm{B}$ haplotypes, though they did not report the distribution in normal population nor describe what constituted the non- $\Delta$ F508 group.

Our findings suggest that it is unlikely that a single common mutation could account for the so-far undetected alleles in the Chilean population. Alternatively, if a single or markedly predominant mutation exists, the lack of linkage disequilibrium could be due to recombination between the markers and the mutation, a remote possibility due to the known low recombination fraction between them. Alternatively, a putative common mutation could have multiple origins, but the available worldwide data supporting tight linkage disequilibrium between most common mutations and close haplotypic frames make this improbable (Estivill et al., 1987). These possibilities can be evaluated in further studies of intragenic microsatellite and single nucleotide polymorphism (SNP) markers.

Mis-attributed paternity or uniparental disomy were not evaluated in this study. Nevertheless, the inheritance of the alleles showed expected Mendelian transmission in all trios and no child had alleles that were absent in the parents, making these confounders unlikely.

Our results have several implications. First, in terms of individual families, the feasibility of the analysis highlights its potential use to provide relevant information regarding carrier status or presymptomatic testing for unaffected relatives of individuals with unknown genotypes, who cannot currently benefit from direct mutation testing or can only do so at expensive costs (Beaudet et al., 1989; Lemna et al., 1990; Riveros et al., 2005).

Regarding the molecular genetics of the disease in our population, the deduction that there could be several additional alleles evidences the challenges in improvement of sensitivity of molecular testing for Chilean patients. To solve this problem, full sequencing of the gene and re-analysis of the haplotypic frameworks of newly found alleles are required.

Other investigators in Latin American countries that have performed extensive analysis of the CFTR gene in their patients have shown the presence of several private mutations of low individual frequency. Visich et al. (2002) found 62 mutations in 220 Argentinean patients, including 6 novel mutations and reaching a detection rate of $84 \%$. Only 6 of these, all of them worldwide common mutations, showed frequencies higher than $1 \%$. In Colombia, Keyeux et al. (2003) found 6 common and 13 rare mutations, including 6 novel ones, in 92 patients, reaching a detection rate of $64 \%$ after denaturing gradient gel eletrophoresis analysis.

No evidence has been found so far of a common Amerindian CF founder mutation. Thus, the disease in our countries probably originated by a group of worldwide common mutations that were introduced from immigrants, as evidenced by their presence on the same haplotypes in European counterparts. In addition, there is an apparently large additional number of mutations, maybe different between countries, and whose origins remain undetermined.

\section{ACKNOWLEDGEMENTS}

This work was funded by Dirección de Investigación, Vice-Rectoría Académica, Universidad del Desarrollo, Santiago, Chile.

The authors wish to thank the clinicians involved in contacting patients and families for the study, and Mrs. María Luisa Guzmán, RN and Sonia Margarit, MSc, for assistance in blood sample collection.

\section{REFERENCES}

ANWAR R, MURRAY K, HEDGE PJ, SMITH JC, MARKHAM AF (1990) DNA sequence analysis of the KM19 locus linked to cystic fibrosis. Design of new oligonucleotides to remove non- specific PCR products. Hum Genet 85: 319-323 
BEAUDET AL, FELDMAN GL, FERNBACH SD, BUFFONE GJ, O'BRIEN WE (1989) Linkage disequilibrium, cystic fibrosis, and genetic counseling. Am J Hum Genet 44: 319-326

CASHMAN SM, PATINO A, MARTINEZ A, GARCIADELGADO M, MIEDZYBRODZKA Z, SCHWARZ M, SHRIMPTON A, FEREC C, RAGUENES O, MACEK M JR (1995) Identical intragenic microsatellite haplotype found in cystic fibrosis chromosomes bearing mutation G551D in Irish, English, Scottish, Breton and Czech patients. Hum Hered 45: 6-12

CFGAC, CYSTIC FIBROSIS GENETIC ANALYSIS CONSORTIUM (1994) Population variation of common cystic fibrosis mutations. Hum Mutat 4: 167177

CUPPENS H, TENG H, RAEYMAEKERS P, DE BOECK C, CASSIMAN JJ (1994) CFTR haplotype backgrounds on normal and mutant CFTR genes. Hum Mol Genet 3: 607-614

DORK T, EL-HARITH EH, STUHRMANN M, MACEK M, JR., EGAN M, CUTTING GR, TZETIS M, KANAVAKIS E, CARLES S, CLAUSTRES M, PADOA C, RAMSAY M, SCHMIDTKE J (1998) Evidence for a common ethnic origin of cystic fibrosis mutation $3120+1 \mathrm{G} \rightarrow \mathrm{A}$ in diverse populations. Am J Hum Genet 63: 656-662

DORK T, MACEK M, JR., MEKUS F, TUMMLER B, TZOUNTZOURIS J, CASALS T, KREBSOVA A, KOUDOVA M, SAKMARYOVA I, MACEK M, SR., VAVROVA V, ZEMKOVA D, GINTER E, PETROVA NV, IVASCHENKO T, BARANOV V, WITT M, POGORZELSKI A, BAL J, ZEKANOWSKY C, WAGNER K, STUHRMANN M, BAUER I, SEYDEWITZ HH, NEUMANN T, JAKUBICZKA S (2000) Characterization of a novel $21-\mathrm{kb}$ deletion, CFTRdele2,3(21 kb), in the CFTR gene: a cystic fibrosis mutation of Slavic origin common in Central and East Europe. Hum Genet 106: 259-268

DORK T, NEUMANN T, WULBRAND U, WULF B, KALIN N, MAASS G, KRAWCZAK M, GUILLERMIT H, FEREC C, HORN G, ET AL. (1992) Intra- and extragenic marker haplotypes of CFTR mutations in cystic fibrosis families. Hum Genet 88: 417-425

ESTIVILL $X$, SCAMBLER PJ, WAINWRIGHT BJ, HAWLEY K, FREDERICK $P$, SCHWARTZ M, BAIGET M, KERE J, WILLIAMSON R, FARRALL M (1987) Patterns of polymorphism and linkage disequilibrium for cystic fibrosis. Genomics 1: 257-263

HEIM RA, SUGARMAN EA, ALLITTO BA (2001) Improved detection of cystic fibrosis mutations in the heterogeneous U.S. population using an expanded, panethnic mutation panel. Genet Med 3: 168-176

HIGHSMITH WE, JR., CHONG GL, ORR HT, PERRY TR, SCHALD D, FARBER R, WAGNER K, KNOWLES MR, WARWICK WJ, SILVERMAN LM (1990) Frequency of the delta Phe508 mutation and correlation with XV.2c/KM-19 haplotypes in an American population of cystic fibrosis patients: results of a collaborative study. Clin Chem 36: 1741-1746

KEREM B, ROMMENS JM, BUCHANAN JA, MARKIEWICZ D, COX TK, CHAKRAVARTI A, BUCHWALD M, TSUI LC (1989) Identification of the cystic fibrosis gene: genetic analysis. Science 245: 1073-1080

KEREM E, KALMAN YM, YAHAV Y, SHOSHANI T, ABELIOVICH D, SZEINBERG A, RIVLIN J, BLAU H, TAL A, BEN-TUR L, ET AL. (1995) Highly variable incidence of cystic fibrosis and different mutation distribution among different Jewish ethnic groups in Israel. Hum Genet 96: 193-197

KEYEUX G, RODAS C, BIENVENU T, GARAVITO P, VIDAUD D, SÁNCHEZ D, KAPLAN JC, ARISTIZABAL G (2003) CFTR mutations in patients from Colombia: implications for local and regional molecular diagnosis programs. Hum Mutat 22: 259

LATHROP G, FARRALL M, O'CONNELL P, WAINWRIGHT B, LEPPERT M, NAKAMURA Y, LENCH N, KRUYER H, DEAN M, PARK M, VANDE WOUDE G, LALUEL J-M, WILLIAMSON R, WHITE $\mathrm{R}$ (1988) Refined linkage map of chromosome 7 in the region of the cystic fibrosis gene. Am J Hum Genet 42: 38-44

LEMNA WK, FELDMAN GL, KEREM B, FERNBACH SD, ZEVKOVICH EP, O'BRIEN WE, RIORDAN JR, COLLINS FS, TSUI LC, BEAUDET AL (1990) Mutation analysis for heterozygote detection and the prenatal diagnosis of cystic fibrosis. N Engl J Med 322: 291-296

LOIRAT F, HAZOUT S, LUCOTTE G (1997) G542X as a probable Phoenician cystic fibrosis mutation. Hum Biol 69: 419-425

MOLINA G, GONZÁLEZ FJ, CAVE R, CORNEJO DE M, NAVARRO S, DEGLIN $M$, MILINARSKY A, CARVALLO P (2002) Estudio clínico-genético molecular de la fibrosis quística en la V Región, Chile. Rev Med Chil 130: 850-858 (In Spanish)

MORRAL N, BERTRANPETIT J, ESTIVILL X, NUNES $\mathrm{V}$, CASALS T, GIMENEZ J, REIS A, VARONMATEEVA R, MACEK M, JR., KALAYDJIEVA L, ET AL. (1994) The origin of the major cystic fibrosis mutation (delta F508) in European populations. Nat Genet 7: 169-175

MORRAL N, LLEVADOT R, CASALS T, GASPARINI P, MACEK M, JR., DORK T, ESTIVILL X (1994) Independent origins of cystic fibrosis mutations $\mathrm{R} 334 \mathrm{~W}, \mathrm{R} 347 \mathrm{P}, \mathrm{R} 1162 \mathrm{X}$, and $3849+10 \mathrm{kbC} \rightarrow \mathrm{T}$ provide evidence of mutation recurrence in the CFTR gene. Am J Hum Genet 55: 890-898

OROZCO L, GONZÁLEZ L, CHÁVEZ M, VELÁZQUEZ R, LEZANA JL, SALDANA Y, VILLARREAL T, CARNEVALE A (2001) XV-2c/KM-19 haplotype analysis of cystic fibrosis mutations in Mexican patients. Am J Med Genet 102: 277-281

OSBORNE L, SANTIS G, SCHWARZ M, KLINGER K, DORK T, MCINTOSH I, SCHWARTZ M, NUNES V, MACEK M, JR., REISS J (1992) Incidence and expression of the $\mathrm{N} 1303 \mathrm{~K}$ mutation of the cystic fibrosis (CFTR) gene. Hum Genet 89: 653-658

RASKIN S, PHILLIPS JA, 3RD, KRISHNAMANI MR, VNENCAK-JONES C, PARKER RA, ROZOV T, CARDIERI JM, MAROSTICA P, ABREU F, GIUGLIANI R, REIS F, ROSARIO NA, LUDWIG N, CULPI L (1997) Cystic fibrosis in the Brazilian population: DF508 mutation and KM-19/XV-2C haplotype distribution. Hum Biol 69: 499-508

REPETTO $G$, POGGI $H$, HARRIS $P$, NAVARRO $H$ SÁNCHEZ I, GUIRALDES E, PÉREZ MA, BOZA ML, HUNTER B, WEVAR ME, MEDIAVILLA M, FORADORI A (2001) Identificación de mutaciones en el gen CFTR en pacientes chilenos con fibrosis quística. Rev Med Chil 129: 841-847 (In Spanish)

RIOS J, ORELLANA O, ASPILLAGA M, AVENDANO I, LARGO I, RIVEROS N (1994) CFTR mutations in Chilean cystic fibrosis patients. Hum Genet 94: 291294

RIVEROS N, RÍOS J (2005) Detección indirecta de portadores de fibrosis quística en dos familias chilenas mediante análisis de polimorfismos en el ADN 
asociados fuertemente al gen CFTR. Rev Med Chil 133: 648-654 (In Spanish)

ROMMENS JM, IANNUZZI MC, KEREM B, DRUMM ML, MELMER G, DEAN M, ROZMAHEL R, COLE JL, KENNEDY D, HIDAKA N (1989) Identification of the cystic fibrosis gene: chromosome walking and jumping. Science 245: 1059-1065

ROSENBLOOM CL, KEREM BS, ROMMENS JM, TSUI LC, WAINWRIGHT B, WILLIAMSON R, O'BRIEN WE, BEAUDET AL (1989) DNA amplification for detection of the XV-2c polymorphism linked to cystic fibrosis. Nucleic Acids Res 17: 7117

ROSENSTEIN BJ, CUTTING GR (1998) The diagnosis of cystic fibrosis: a consensus statement. Cystic Fibrosis Foundation Consensus Panel. J Pediatr 132: 589-595

SHOSHANI T, AUGARTEN A, GAZIT E, BASHAN N,
YAHAV Y, RIVLIN Y, TAL A, SERET H, YAAR L, KEREM E (1992) Association of a nonsense mutation (W1282X), the most common mutation in the Ashkenazi Jewish cystic fibrosis patients in Israel, with presentation of severe disease. Am J Hum Genet 50: 222-228

THOMSON G (1995) Mapping disease genes: family-based association studies. Am J Hum Genet 57: 487-498 (AFBAC program documentation at http:// allele5.biol.berkeley.edu/afbac.html)

VISICH A, ZIELENSKI J, CASTANOS C, DIEZ G, GRENOVILLE M, SEGAL E, BARREIRO C, TSUI LC, CHERTKOFF L (2002) Complete screening of the CFTR gene in Argentine cystic fibrosis patients. Clin Genet 61: 207-213 
